\title{
Možnosti zmírnění dopadů změny klimatu využitím území chráněných pro akumulaci povrchových vod
}

\author{
ROMAN KOŽíN, MARTIN HANEL, LADISLAV KAŠPÁREK, MARTINA PELÁKOVÁ, \\ ADAM VIZINA, PAVEL TREML
}

Klíčová slova: vodní nádrže - deficit - změna klimatu - adaptace

\section{SOUHRN}

V České republice existuje od počátku 20. století seznam lokalit vhodných pro akumulaci povrchových vod (LAPV). Tento seznam byl do současnosti redukován z několika set na 65 lokalit, které jsou popsány v Generelu LAPV. Pro LAPV byly v minulosti zpracovány základní údaje o možném objemu nádrží, o jejich dopadu na zástavbu, ochranu prírody atp. V souvislosti s možnou změnou klimatu v budoucích desetiletích je nezbytné prověřit, nakolik se zvýší četnost a intenzita suchých období a nakolik by byly potenciální nádrže na LAPV schopny tyto negativní změny kompenzovat. Předložený článek podává informaci o počátku řešení této problematiky, jehož hlavním výsledkem budou podklady pro aktualizaci Generelu LAPV jak z hlediska vhodnosti jednotlivých lokalit, tak z hlediska jejich parametrů.

\section{ÚVOD}

$\checkmark$ souvislosti s predpokládanou změnou klimatu v průběhu 21. století je ve světě i v ČR věnována značná pozornost návrhům adaptačních opatření vedoucích ke zmírnění dopadů klimatické změny a k zajištění dlouhodobě udržitelného využívání vodních zdrojů. Je zřejmé, že adaptační opatření je vhodné podle míry předpokládané změny diverzifikovat, nicméně naplníli se projekce klimatických modelů, budou pravděpodobně klíčová opatření vedoucí k navýšení (respektive ke kompenzaci poklesu) vodních zdrojů v povodí. Z dosavadních zkušeností při řešení problému nedostatku vodních zdrojů $v$ důsledku probíhajících změn klimatu vyplývá, že z těchto opatření jsou z hlediska efektivity a proveditelnosti často nejvhodnější opatření technická, mezi nimi i rekonstrukce starých či konstrukce nových vodních nádrži (viz např. Hanel aj., 2011; Horáček aj., 2012).

$\checkmark$ ČR existuje od počátku 20. století seznam lokalit vhodných pro akumulaci povrchových vod (LAPV). Tento seznam byl do současnosti redukován z několika set na 65 lokalit, které jsou popsány v Generelu LAPV (MZe a MŽP, 2011). Pro LAPV byly v minulosti zpracovány základní údaje o možném objemu nádrží, o jejich dopadu na zástavbu, ochranu prírody atp. Dosud používané hydrologické podklady, které jsou pro funkci potenciálních nádrží rozhodující, pocházejí ze Směrného vodohospodářského plánu z let 1970-1975 a byly převážně odvozeny hydrologickou analogií. V řadě prípadů tak neodpovídají současnému vývoji hydrologických poměrů a vyžadují zpřesnění. Navíc je vzhledem k předpokládanému zvyšování variability hydrologického režimu v důsledku změny klimatu nezbytné prověřit schopnost potenciálních nádrží plnit své funkce i v prípadě déletrvajících a častěji se opakujících období sucha.

Z tohoto důvodu bylo v polovině roku 2014 zahájeno řešení projektu s názvem Možnosti kompenzace negativních dopadů klimatické změny na zásobování vodou a ekosystémy využitím lokalit vhodných pro akumulaci povrchových vod. Projekt spolufinancuje Technologická agentura ČR a na jeho řešení se kromě Výzkumného ústavu vodohospodářského T. G. Masaryka (VúV TGM) podílí i Česká zemědělská univerzita. Projekt si klade za cíl reálně posoudit možnosti kompenzace nedostatku vodních zdrojů způsobeného změnou klimatu pomocí nádrží na LAPV s přihlédnutím zejména k (1) míre zranitelnosti jednotlivých povodí a (2) pravděpodobné zabezpečenosti funkce případných nádrží v podmínkách klimatické změny. K tomu využije (3) zpřesněné hydrologické údaje týkající se jednotlivých LAPV, které jsou získávány na základě doplněných datových zdrojů (pokud existují), i účelového automatického měření v profilech vybraných LAPV, které probíhá od konce roku 2014. Využití hájených lokalit k realizaci vodních nádrží by mělo jako technické rešení nastoupit až tehdy, když budou vyčerpány možnosti ostatních opatření k zajištění vodohospodářských služeb. V prípadě, kdy dopady klimatických změn nebudou řešitelné jinými prostředky, budou alternativně posouzeny i (4) možnosti zvýšení retence vody $v$ povodí pomocí opatření v ploše povodí, včetně vlivu na celkovou hydrologickou bilanci zejména v obdobích nedostatku vodních zdrojů.

Již v minulých letech vzniklo několik studií, které se zabývaly vyhodnocením potenciálu LAPV vzhledem k možnostem kompenzace dopadů změny klimatu. Např. Peláková a Boersema (2005) a Hanel aj. (2011) na základě porovnání průměrné změny nedostatkových objemů $v$ důsledku změny klimatu (popsanou různými scénáři) konstatují, že ve většině prípadů jsou schopny nádrže na LAPV kompenzovat (za určitých zjednodušujících předpokladů) změny nedostatkových objemů. Hanel aj. (2013) tyto studie rozšírili o vyhodnocení změn celého rozdělení nedostatkových objemů. Žádná z výše zmíněných studií nicméně neřeší zabezpečenost zásobní funkce posuzovaných nádrží - tj. nedostatkové objemy jsou porovnávány s potenciálním objemem nádrží a navíc se předpokládá, že na počátku deficitního období jsou nádrže plné. Tyto předpoklady mohou do jisté míry ovlivnit hodnocení využitelnosti jednotlivých nádrží na LAPV.

Cílem článku je podat základní informaci o projektu a seznámit s prvními výsledky řešení, tj. zejména s vyhodnocením reálně dostupných objemů nádrží a s jejich porovnáním s nedostatkovými objemy pro povodí 3. rádu. Uvažovány jsou i potenciální prevevody vody a využití nádrží položených na horním toku povodí. $V$ následující kapitole jsou stručně popsány jednotlivé LAPV, vodoměrné stanice VÚVTGM a základní prístup k řešení projektu. Kapitola Hydrologická bilance pro profily LAPV popisuje kalibraci modelu Bilan pro profily LAPV. V kapitole Vyhodnocení vodohospodářské bilance je představeno zjednodušené vodohospodářské řešení zásobní funkce nádrží na LAPV. Poznatky jsou shrnuty v Závěru. 


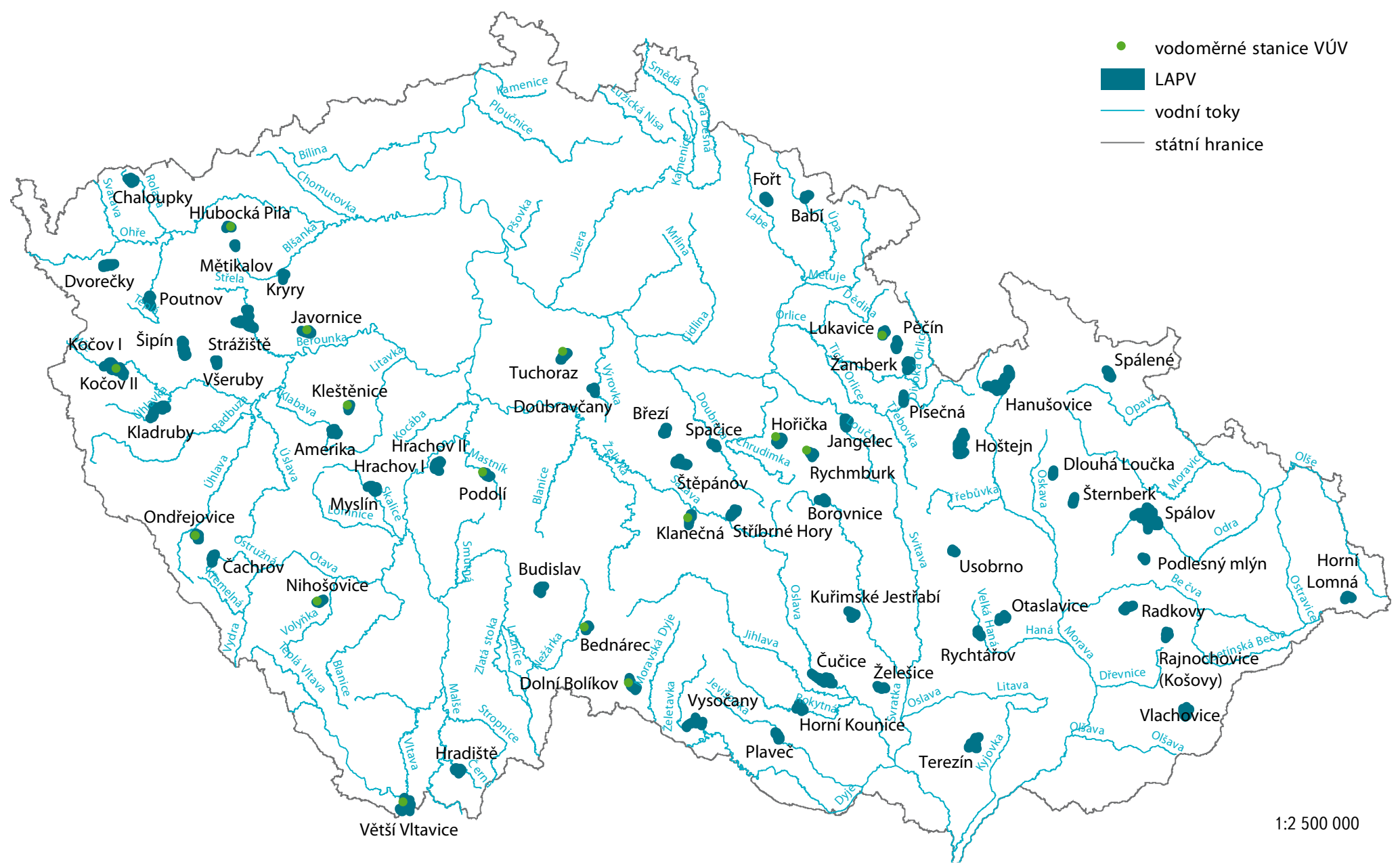

Obr. 1. Mapa ČR s rozmístěním 65 LAPV a 17 účelových stanic

Fig.1. Map of the Czech Republic with 65 localities suitable for accumulation of surface water and 17 gauging stations

\section{LAPV A PŘÍSTUP K ŘEŠENÍ JEJICH FUNKCE V PODMÍNKÁCH ZMĚNY KLIMATU}

\section{LAPV a účelová měření}

V aktuální podobě Generelu LAPV je popsáno 65 lokalit (viz obr. 1) včetně jejich využití, potenciálních objemů, identifikace střetů se zástavbou, komunikacemi, zájmy ochrany prírody aj. Prríslušnost LAPV k oblastem povodí je patrná z tabulky 1. Nejvíc LAPV je v oblasti povodí horního a středního Labe (13), nejméně v povodí Odry (3). Suma potenciálních objemů je nicméně nejvyšší $\checkmark$ oblastech povodí Moravy (390,9 mil. m³), Odry (322,9 mil. m³) a Berounky $\left(233,2\right.$ mil. $\left.\mathrm{m}^{3}\right)$.

Za účelem zpřesnění hydrologických podkladů v profilech LAPV, pro které nejsou k dispozici spolehlivá data z pozorovacích sítí ČHMÚ a podniků povodí, bylo zřizeno 17 vodoměrných stanic s kontinuálním měřením průtoků (viz obr. 1). Stanice byly umístěny zpravidla, pokud to podmínky umožňovaly, do profilu pod uvažovanou hráz, aby mohlo měření pokračovat i v prípadě výstavby nádrže. Stanice se skládá z kovového tubusu, na kterém je připevněný plastový vodočet a uvnitř zavěšena hladinoměrná sonda - Levelogger značky Solinst. Data jsou stahována manuálně, zpravidla při provádění hydrometrických měření.

\section{Metodika řešení projektu}

Zranitelnost jednotlivých povodí k profilům LAPV vưči změně klimatu (pozornost je věnována zejména obdobím sucha a s nimi spojeným nedostatkovým objemům) je posuzována jednak vyhodnocením dopadů již probíhajících změn a dále $s$ využitím scénářů změn klimatu. Na základě návrhových údajů nádrží na LAPV je provedena simulace a vyhodnocení zabezpečenosti zásobní funkce jednotlivých nádrží pro současné podmínky, simulace využívající scénáře změny klimatu se připravují. Jelikož není jisté, které z nádrží se budou realizovat, jsou jednotlivé nádrže posuzovány převážně odděleně. Tento postup umožňuje identifikaci povodí potenciálně nejohroženějších změnami klimatu a zároveň umožňuje posoudit, zda a do jaké míry by byly jednotlivé nádrže na LAPV schopny tyto změny kompenzovat, zvláště vzhledem k možným změnám časového i plošného rozložení množství srážek.

Uvažované scénáre změny klimatu využívají nejnovější simulace klimatických modelů, které byly provedeny v rámci projektu CMIP5 (Taylor aj., 2012), respektive navazujícího projektu CORDEX (Giorgi aj., 2006). Projekt CMIP5 poskytuje výstupy globálních klimatických modelů (prostorové rozlišení 100 km a více) pro dlouhá časová období (standardně 1850-2100), což umožňuje vyhodnocení simulované dlouhodobé variability srážek, teploty i odtoku. Regionální klimatické modely z projektu CORDEX mají podstatně lepší prostorové rozlišení (50km a 11 km), nicméně jsou dostupné zpravidla pro období 1950-2100. Simulace z obou projektů 
využívají scénáře vývoje koncentrací skleníkových plynů (RCP) (Meinshausen aj., 2011) a v prípadě obou projektů jsou dostupné desítky simulací. Simulace jsou upraveny pomocí standardních metod statistického downscalingu (např. Hanel a Vizina, 2013) tak, aby je bylo možno využít pro hydrologické modelování. Zároveň jsou využity referenční scénáře změny klimatu, které jsou výstupem projektu TAČR Podpora dlouhodobého plánování a návrhu adaptačních opatření v oblasti vodního hospodářství v kontextu změn klimatu viz rscn.vuv.cz.

\section{HYDROLOGICKÁ BILANCE PRO PROFILY LAPV}

Povodí dané profilem LAPV se ve většině případů neshoduje s povodím, které je uzavřené vodoměrnou stanicí ČHMÚ. Neexistují tedy pro něj měřené průtoky. Hydrologická bilance $v$ profilech LAPV je tak počítána pomocí konceptuálního modelu Bilan v měsičním kroku s využitím hydrologické analogie. Bilan je nakalibrován na povodí s měřenými průtoky (analogon) a parametry takto nakalibrovaného modelu jsou přeneseny na povodí LAPV.

Hlavním výstupem modelování je celkový odtok z povodí LAPV, který pak sloužl jako vstup při rešení vodohospodářké bilance. Pro spolehlivější výpočet bilance byly použity co možná nejdelší pozorované řady hydrometeorologických veličin.

\section{Data}

Vzhledem k potřebě interpolovat srážky a teplotu vzduchu na 65 povodích nepravidelně rozprostřených po celé ČR byly vytvořeny rastry srážek a teploty v pravidelné síti. Pro oblast Čech byl vytvořen rastr měsíčních srážek z historických staničních dat v období 1879-2003. Pro interpolaci byla použita metoda respektující variabilitu v ploše i nadmořskou výšku. Pro vytvoření rastru teploty byl využit dataset pocházející od Climatic Research Unit (viz Harris a Jones, 2014), který byl pro ČR přeprojektován do pravidelné sítě $2 \times 2 \mathrm{~km}$ a korigován podle výškového gradientu $0,65^{\circ} \mathrm{C} / 100 \mathrm{~m}$. Vznikl tak rastr měsíční teploty pro území ČR pro období 1901-2013

Pro simulaci hydrologické bilance v LAPV ležících na území Čech byly použity srážky a teplota z období 1901-2010. Srážky a teplota v období 1901-1960 pochází z námi vytvořených rastrů. Data z období 1961-2010 pochází z rastru vytvořeného Štěpánkem aj. (2011), který má rozlišení $25 \times 25$ km. Na území Moravy a Slezska byla pro simulaci hydrologické bilance použita pouze data od Štěpánka aj. (2011) z období 1961-2010.

\section{Tabulka 1. Počty LAPV v jednotlivých oblastech povodí}

Table 1. The number of $L A S W$ in each river basin district of the Czech Republic

\section{Název oblasti povodí}

Počet LAPV
Srážky i teplota vzduchu z námi vytvořených rastrů byly validovány s historicky interpolovanými daty na povodí i s rastrovými daty od Štěpánka aj. (2011). Obecně jsou všechny datové zdroje konzistentní, v prrípadě rozporů byly individuálně zvoleny nejvěrohodnější datové zdroje.

\section{Kalibrace modelu Bilan}

Bilan (viz Vizina aj., 2015) je konceptuální model hydrologické bilance, který je řizen osmi parametry. Srážky jsou transformovány na odtok pomocí soustavy lineárních nádrží. Více o modelu lze nalézt na bilan.vuv.cz.

Jak již bylo uvedeno výše, Bilan byl kalibrován nejprve na analogon, který byl vybrán tak, aby povodí LAPV bylo jeho součástí anebo se nacházelo v bezprostřední blízkosti. Tím je zaručen předpoklad stejných parametrů a výparů na analogonu i povodí LAPV. Následně byly parametry z analogonu preneseny na povodí LAPV. Interpolované srážky a teplota vzduchu na povodí LAPV sloužily jako nový vstup do již nakalibrovaného modelu (z analogonu), výsledkem simulace jsou řady odtoků v profilech LAPV.

\section{VYHODNOCENÍ VODOHOSPODÁŘSKÉ BILANCE}

\section{Uvažované indexy}

Vodohospodářská (VH) bilance byla řešena pro celé potenciální objemy navrhovaných nádrží. Bylo provedeno zjednodušené VH řešení (rovnice 1 až 3), kde se hledal maximální možný odběr se $100 \%$ zabezpečením pro daný potenciální objem. Výpar z hladiny nádrže uvažován nebyl. Výpočet byl proveden $\checkmark$ měsíčním kroku na historických průtocích simulovaných Bilanem, pro LAPV v Čechách za období 1901-2010, na Moravě a Slezsku pak za období 1961-2010.

$S_{i}=I_{i}-O_{i}$

$D_{i+1}=\min \left(0, D_{i}+S_{i+1}\right) ; D_{0}=0$

$V_{100 \%}=-\min \left(D_{i}\right)$

S - zásoba vody v nádrži, I - prítok, O - odtok, D - deficit v nádrži, V zabezpečený objem nádrže pro požadovaný odtok, všechny veličiny jsou $\mathrm{v} \mathrm{m}^{3}$

\begin{tabular}{|c|c|c|c|}
\hline & & objem [mil. $\mathrm{m}^{3}$ ] & objem [mil. $\mathrm{m}^{3}$ ] \\
\hline Oblast povodí horního a středního Labe & 13 & 138,5 & 10,7 \\
\hline Oblast povodí horní Vltavy & 7 & 97,4 & 13,9 \\
\hline Oblast povodí Berounky & 10 & 233,2 & 23,3 \\
\hline Oblast povodí dolní Vltavy & 6 & 56,9 & 9,5 \\
\hline Oblast povodí Ohře a dolního Labe & 6 & 94,9 & 15,8 \\
\hline Oblast povodí Odry & 3 & 322,9 & 107,6 \\
\hline Oblast povodí Moravy & 11 & 390,9 & 35,5 \\
\hline Oblast povodí Dyje & 9 & 134,2 & 14,9 \\
\hline
\end{tabular}


Pro povodí 3. rádu byla provedena analýza deficitních objemů z měsíčních průtoků za období 1981-2010. Cílem bylo zjistit, jak velký deficit vznikne, kdyby každé povodí mělo kompenzovat odběr daný součtem odběrů podzemních a povrchových vod, vypouštění a minimálního zůstatkového průtoku (MZP), viz rovnici (4). MZP vypočtený z měsíčních průtoků podle rovnice (5) odpovídá hodnotám MZP počítaných na základě nové metodiky, kterou zpracoval Balvín aj. (2015) pro denní průtoky. Deficitní objemy pro jednotlivá povodí jsou počítána za pomoci rovnic (1) a (2), kde prrítok je průtok $\checkmark$ závěrovém profilu povodí a odtok je odběr definovaný rovnicí (4). Pro každý rok je posléze vybrán maximální deficit. Deficity, které se rovnají nule, nejsou uvažovány.

Troutman (1976, v McMahon aj., 2007) uvádí, že pokud $a<1$, viz rovnici (10), tak maximální deficit má zpravidla Gumbelovo (EV1) rozdělení. Při vykreslení deficitu jako závislosti na redukované proměnné Gumbelova rozdělení y je vidět lineární vztah, jak ukazuje obr. 2. N-letý deficit se pak vypočte s využitím koeficientů z regresní prímky a redukované proměnné pro $\mathrm{N}$ let $\mathrm{y}_{\mathrm{N}}$.

$O d=P O D+P O V-V Y P+M Z P$

$M Z P=0,73 * Q_{10}$

$y=-\ln (-\ln (p))$

$p=1-\left(\frac{i-0,3}{N+0,4}\right)$

$T=\frac{1}{1-p}$

$y_{N}=-\ln \left(-\ln \left(1-\frac{1}{N}\right)\right.$

Od - celkový odběr z nádrže, $P O D$ - odběr podzemních vod, POV - odběr povrchových vod, VYP - vypouštění, MZP - minimální zůstatkový průtok, $Q_{10}=90 \%$ kvantil z průměrných měsíčních průtoků, $y$ - redukovaná proměnná Gumbelova rozdělení, $i$ - pořadí dle velikosti deficitu (řazeno od nejvyššího), $p$ - pravděpodobnost, $N$ - počet let, $T$ - doba opakování, $y_{N}$ - Gumbelova redukovaná proměnná pro N let opakování

Kromě VH řešení byly spočteny dva základní indexy charakterizující VH nádrže - koeficient nalepšení a a standardizovaný př́tok m, který např. Vogel a Bolognese (1995) označují jako index odolnosti. Ukázali, že nádrže, které mají $m<0,2$, mají tendenci se naplňovat několik let nebo i desetiletí $v$ př́padě, že nastane porucha. Podle $m$ Ize také rozlišit nádrže se sezonním nebo víceletým ř́zením. Pokud $m \geq 1$ nebo $m \geq C v$, Ize nádrž chápat jako sezonní, v opačném př́padě jako víceletou. Obě pravidla jsou konzistentní, jak ukázali McMahon aj. (2007). Indexy definují rovnice (10) a (11).

$a=Q_{n} / Q_{a}$

$m=\left(\frac{1-a}{C v}\right)$

$Q_{n}$ - nalepšený odtok z nádrže, $Q_{a}$ - dlouhodobý průměrný průtok, $C V$ - koeficient variace ročních průměrných průtoků

Pokud rozdělíme nádrže na základě $m$, vyjde, že sezonní řizení připadá na 27 lokalit, které se nacházejí převážně na území Čech. U ostatních 38 nádrží by bylo pravděpodobně řízení víceleté.

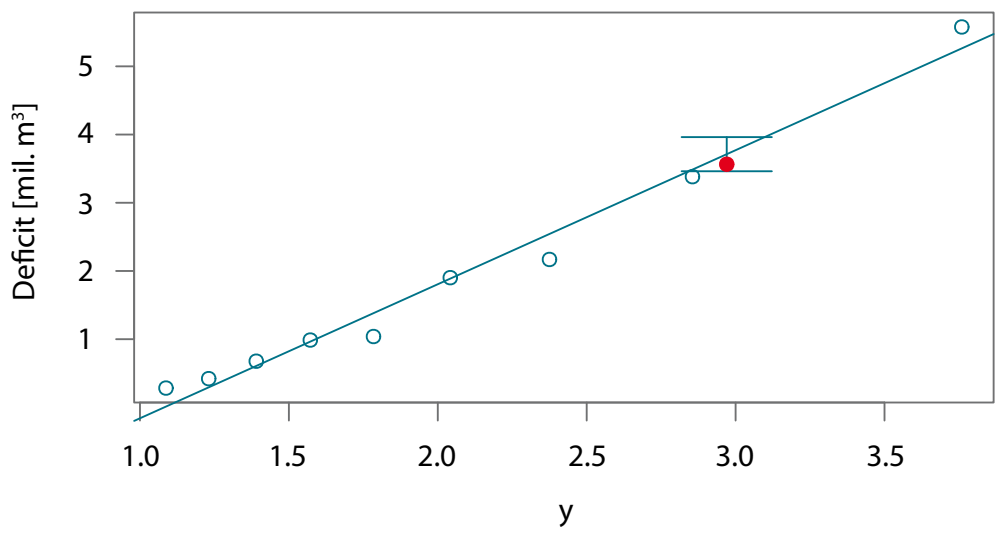

Obr. 2. Maximální deficitní objemy [mil. $\mathrm{m}^{3}$ ] na povodí Divoké Orlice s vyznačeným 20letým deficitem spočteným podle regrese a jeho intervalem spolehlivosti; červeně je deficit spočtený lineární aproximací

Fig. 2. Maximum deficit volumes [mil. $\mathrm{m}^{3}$ ] for Divoká Orlice catchment; the 20-year deficit volume estimated from linear regression together with the corresponding $90 \%$ confidence interval and the empirical estimate (red)

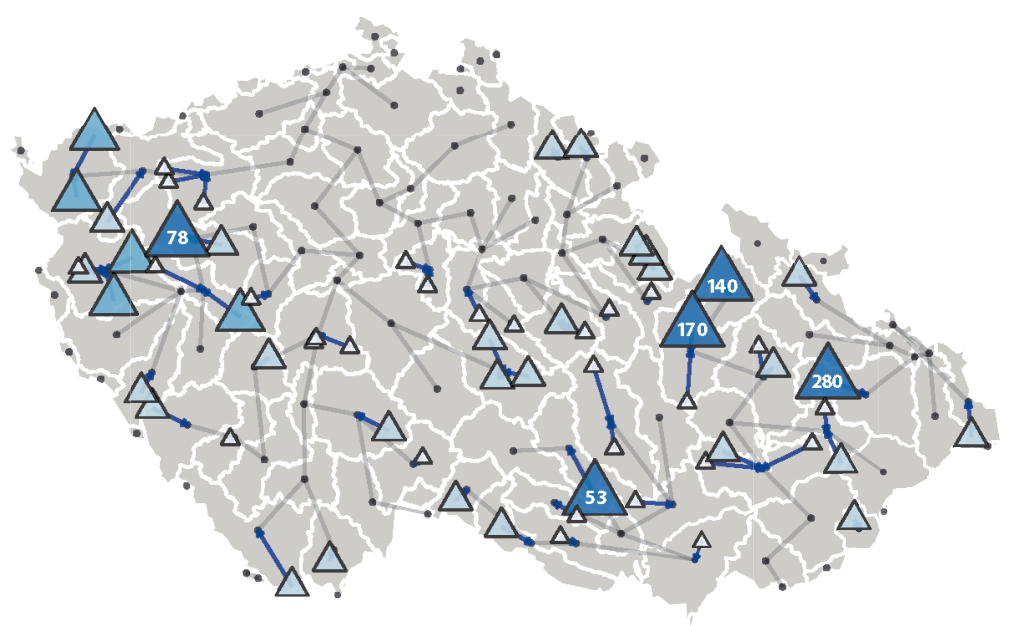

\section{$\Delta[0,10] \triangle(10,25] \triangle(25,50] \triangle(50, \operatorname{lnf}]$}

Obr. 3. Potenciální objemy nádrží na LAPV [mil. m³]; černě je znázorněna sít povodí 3. řádu; modře jsou připojeny nádrže na LAPV

Fig. 3. Potential volumes of reservoirs at LASW [mil. $\mathrm{m}^{3}$ ] and connection of the reservoirs into the system of 3rd order catchments; black lines represent the system of 3rd order catchments; reservoirs at LASW are connected with blue lines

\section{Předběžné vyhodnocení potenciálu nádrží na LAPV}

Na obr. 3 jsou znázorněné potenciální dostupné objemy $\left(V_{\text {pot }}\right)$ nádrží na LAPV. Nejvyšší kapacitu mají LAPV na Moravě - tj. Spálov na Odře (280 mil. m³), Hoštejn na Březné (170 mil. m³), Hanušovice na Moravě (140 mil. m³) a Čučice na Oslavě (53 mil. m³). Další lokality s vyššími potenciálními objemy se nacházejí v povodí horní Ohře (např. Chaloupky, Dvorečky), Mže (Šipín, Kladruby), Střely (Strážiště) a Berounky (Amerika). Průměrný potenciální objem je 23 mil. m³, pět nádrží má potenciální objem nižší než 5 mil. m³ (Písečná na Potočnici, Doubravčany na Výrovce, Hrachov I na Brzině, Mětikalov na Liboci a Kryry na Podvineckém potoce). 
Pro představu o zabezpečenosti zásobního objemu byl vyčíslen i odběr, který je možno dodávat se $100 \%$ zabezpečeností $V_{\text {poo\% }}$ z rovnice (3). Porovnání $V_{100 \%}\left[\mathrm{mil} . \mathrm{m}^{3} / \mathrm{rok}\right] \mathrm{s}$ potenciálním objemem nádrží $V_{\text {pot }}$ [mil. m³] udává obr. 4 (nahoře). Pro 16 LAPV tvoří $V_{100 \%}$ méně než polovinu potenciálního objemu, to se týká i výše jmenovaných velkých nádrží Hoštejn a Spálov. Naopak, pro 18 LAPV je $V_{100 \%}$ stejný nebo větší než $V_{\text {pot }}$

Dalším ukazatelem zabezpečenosti potenciálního objemu je koeficient $m$ z rovnice (11). $V$ prípadech, kdy je $m$ malé (např. $<0,2-$ tj. koeficient variace je $\checkmark$ porovnání s relativním nalepšením velký), může docházet k problémům se znovu naplněním nádrže po poruše. Hodnotu koeficientu $m$ ukazuje obr. 4 (dole). Zejména pro LAPV nacházející se na severovýchodě ČR vycházejí hodnoty nižší než 0,2 . $V$ sadě pěti lokalit $s m<0,2$ jsou opět velké nádrže Hoštejn a Spálov. Z nádrží, pro které vycházel nepř́iznivý poměr $V_{100 \%} / V_{\text {pot }}$, je to dále Spálené na Opavici.

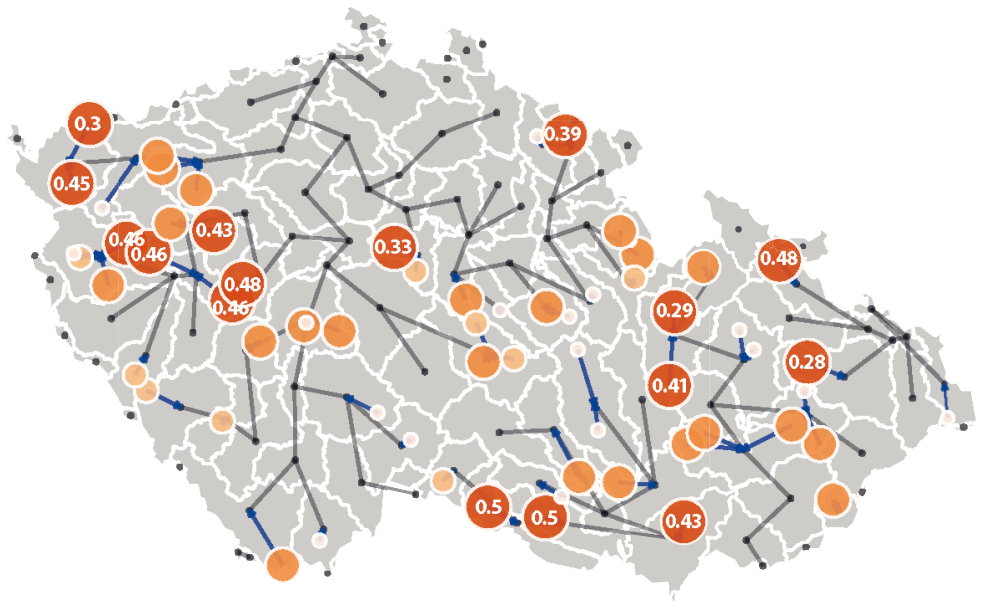

$$
\begin{gathered}
100 \% \text { zabezpečený } \\
\text { objem }\left[\% \mathrm{~V}_{\text {pot }}\right]
\end{gathered} \text { [0,0.5] } \bigcirc(0.5,0.8] \odot(0.8,1] \quad(1, \mathrm{Inf}]
$$

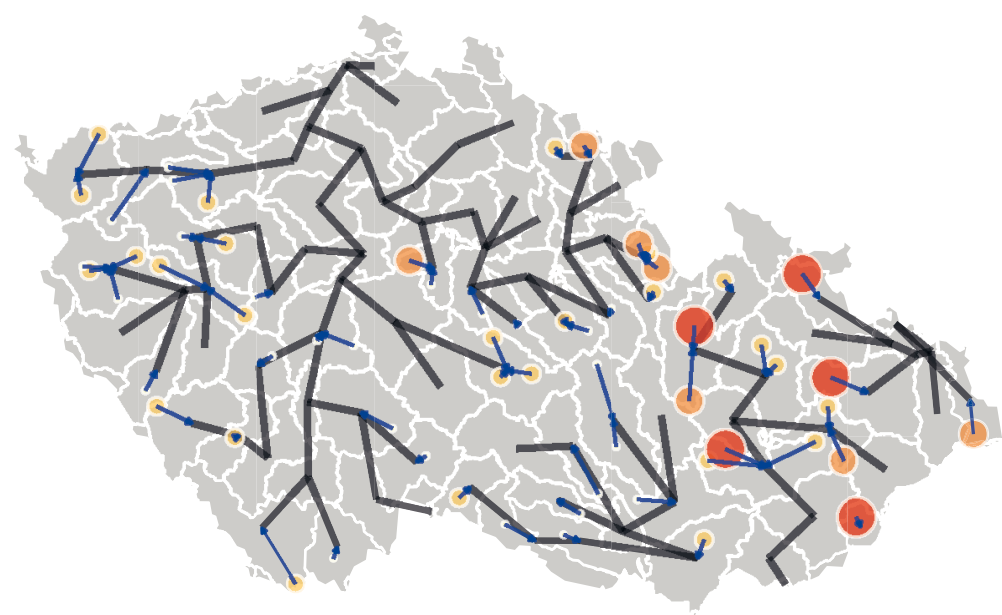

$m[-] \bigcirc[0,0.2] \bigcirc(0.2,0.5] \bullet(0.5,1] \quad(1, \operatorname{lnf}]$

Obr. 4. (nahoře) Poměr $V_{100 \%}\left[\right.$ mil. $\mathrm{m}^{3} /$ rok $]$ a $V_{\text {pot }}$ [mil. $\left.\mathrm{m}^{3}\right]$; (dole) koeficient $m$ z rovnice (11); černě je znázorněna sít povodí 3. rádu; modře jsou připojeny nádrže na LAPV

Fig. 4. (above) Ratio $V_{\text {inog }}$ [mil. $\mathrm{m}^{3} /$ year] to $V_{\text {pot }}$ [mil. $\mathrm{m}^{3}$ ]; (below) koefficient $m$ from eq. (11); black lines represent the system of 3rd order catchments; reservoirs at LASW are connected with blue lines
Efektivita nádrže není dána pouze pravděpodobností, s jakou nádrž dokáže zabezpečit určitý odběr, ale Ize ji chápat i ve vztahu k možnosti kompenzace deficitu v př́slušném povodí, dále po toku nebo v případě převodu vody také $\checkmark$ prrilehlých povodích. Předpokladem takového hodnocení nádrží je i vyčíslení př́slušných deficitů v území, jelikož ty spoluurčují optimální zásobní objem. Pro toto řešení jsme využili výsledků projektu Strategie ochrany před negativními dopady povodní a erozními jevy prírodě blízkými opatřeními v České republice, konkrétně odhady hydrologické bilance pro povodí 3. rádu včetně užívání vod (Beran a Hanel, 2015), které umožňují vyčíslení deficitů včetně jejich rozdělení pravděpodobnosti (viz kapitolu Uvažované indexy).

Na obr. 5 jsou znázorněny odhady pětiletého a dvacetiletého nedostatkového objemu [mil. $\mathrm{m}^{3}$ ]. Vysoké nedostatkové objemy pro povodí 3. rádu často korespondují s intenzivním užíváním vod (např. povodí 1-05-03 - Jizera od Klenice po ústí, 1-09-02 - Želivka, 4-13-02 - Morava od Olšavy po Myjavu).
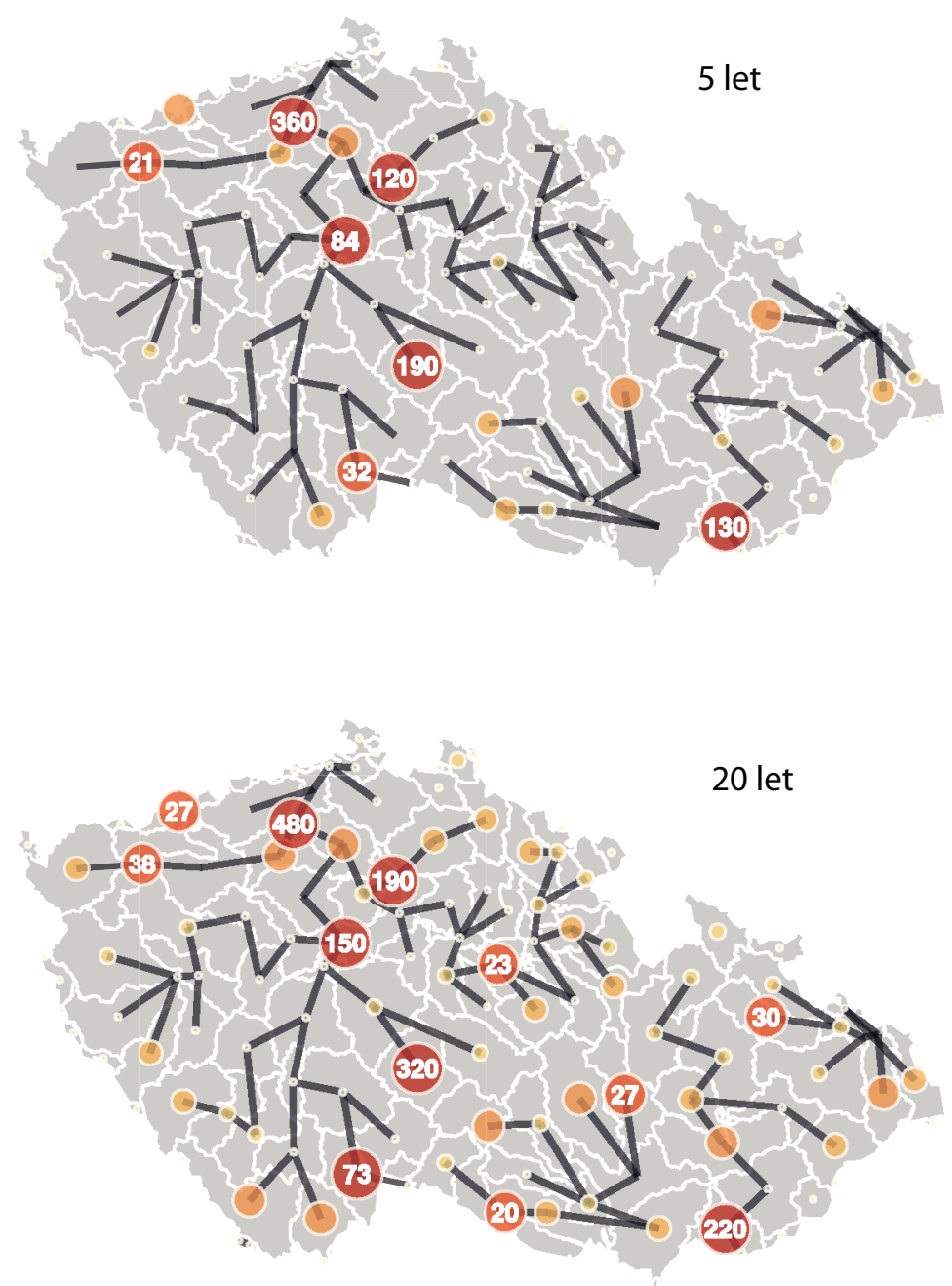

deficitní objem [mil. $\left.\mathrm{m}^{3}\right]$

$(0,2.5] \bullet(2.5,5] \odot(5,10] \bigcirc(10,20] \bigcirc(20,50]$ $(50, \operatorname{lnf}]$

Obr. 5. Odhad nedostatkových objemů s dobou opakování 5 a 20 let; černě je znázorněna sít povodí 3. rádu

Fig. 5. Estimated 5- and 20-years deficit volumes [mil. m³]; black lines represent the system of 3rd order catchments 
Schopnost nádrží na LAPV kompenzovat tyto nedostatkové objemy byla posuzována $v$ několika variantách: (1) deficit pro povodí 3. rádu byl porovnán s objemem nádrží $\left(V_{100 \%}\right)$, které se v tomto povodí nacházejí, (2) deficit pro povodí 3. rádu byl porovnán s objemem všech nádrží $\left(V_{100 \%}\right)$ nacházejících se $\checkmark$ daném povodí a v povodích jeho prítoků a (3) byly navíc uvažovány prevody vody. Možné převody vody byly identifikovány automaticky na základě prostorové analýzy tak, že pro každou nádrž byl zaveden převod do maximálně jednoho povodí, jehož hranice je blíž než 50 km od nádrže. Pokud je takových povodí víc, je zvoleno povodí s nejvyššími deficity. Toto řešení je pouze orientační, jelikož předpokládá, že veškerá voda z relevantních nádrží (podle variant (1)-(3)) je dostupná pro kompenzaci nedostatkového objemu na daném povodí 3. rádu. Poměr nedostatkového objemu po kompenzaci k původnímu nedostatkovému objemu uvádí obr. 6 (nahoře pro variantu (1)+(3), dole pro variantu (2)+(3)), účinek převodů je znázorněn též.
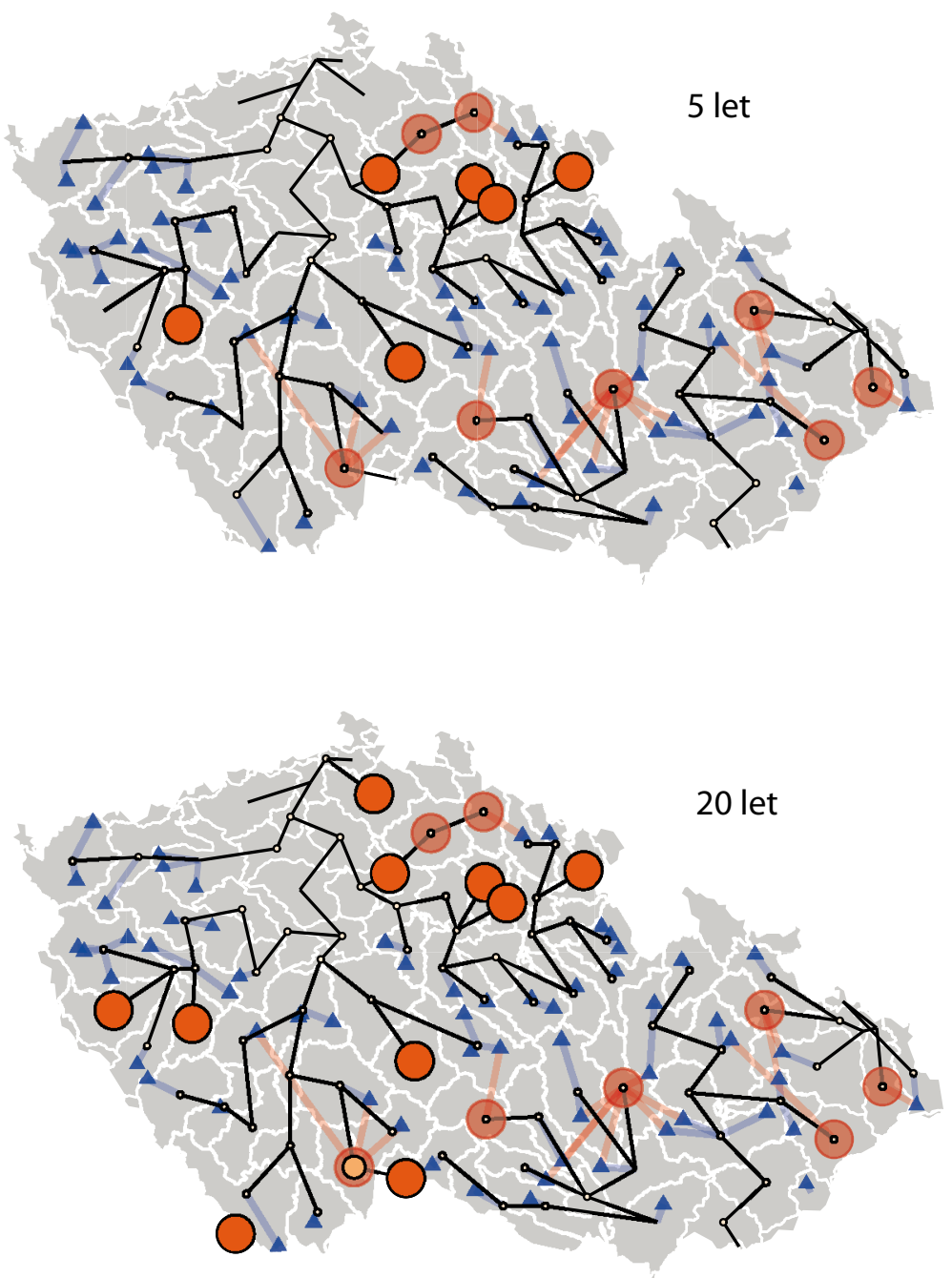

poměr nesaturovaného deficitu [-]

$$
\text { - }(-\operatorname{lnf}, 0] \bigcirc(0.5,0.75] \bigcirc(0.75,1]
$$

Obr. 6. Velikost nedostatkového objemu, který není možno kompenzovat nádržemi na LAPV nacházejícími se v příslušném povodí 3. řádu (nahoře) a nádržemi přispívajícími do př́slušného povodí (dole); černě je znázorněna sít povodí 3. rádu; modře jsou připojeny nádrže na LAPV; možné převody vody jsou znázorněny červeně; výsledky bez uvažovaných převodů jsou vyznačeny pomocí kruhů bez ohraničení
Fig. 6. Fraction of deficit volume that cannot be compensated by reservoirs at LASW from the respective 3rd order catchment (above) and together with all reservoirs upstream (below); black lines represent the system of 3rd order catchments; reservoirs at LASW are connected with blue lines; possible water transfers are indicated by red lines

Za těchto zjednodušených předpokladů platí, že kromě povodí, na kterých se LAPV nenachází, jsou deficity relativně účinně kompenzovány. Nicméně pro osm povodí 3. rádu (1-05-01 - Jizera po Kamenici a Kamenice, 1-05-02 Jizera od Kamenice po Klenici a Klenice, 1-07-02 - Rybná a Lužnice od Rybné po Nežárku, 4-16-01 - Jihlava po Oslavu, 4-15-02 - Svitava, 2-02-02 - Moravice, 2-03-01 - Ostravice, 4-11-01 - Vsetínská Bečva a Rožnovská Bečva) Ize pětiletý i dvacetiletý nedostatkový objem kompenzovat pouze s využitím převodů.

\section{ZÁVĚR}

Byly shromážděny dostupné meteorologické a hydrologické podklady pro stanovení hydrologické a vodohospodářské bilance pro nádrže na LAPV. Pro tyto nádrže byly stanoveny základní vodohospodářské ukazatele a byl odvozen 100\% zabezpečený objem. Ten byl porovnán s objemem potenciálním. Pro povodí 3. rádu byly odhadnuty pětileté a dvacetileté nedostatkové objemy (uvažováno bylo i užívání vod včetně zachování minimálního zůstatkového průtoku). Tyto nedostatkové objemy byly porovnávány se $100 \%$ zabezpečenými objemy nádrží v príslušných povodích i v povodích do těchto povodí prisispivajících.

\section{Hlavní poznatky lze shrnout následovně:}

— pro pozorované obdobíjsou vysoké nedostatkové objemy (z hlediska plošného rozložení) primárně spojené s uživáním vody;

- většina nedostatkových objemů může být teoreticky kompenzována pomocí nádrží na LAPV;

— vyčíslení reálné schopnosti kompenzace nedostatkových objemů vyžaduje podrobnější řešení;

— optimální objemy nádrží na LAPV mohou být v řadě prípadů odlišné od objemů potenciálních.

Prezentované rešení učinilo řadu zjednodušujících předpokladů, které budou do jisté míry eliminovány v průběhu dalšího řešení projektu.

\section{Poděkování}

Tento článek vznikl v rámci řešení projektu Možnosti kompenzace negativních dopadů klimatické změny na zásobování vodou a ekosystémy využitím lokalit vhodných pro akumulaci povrchových vod (TA04020501), který je spolufinancován Technologickou agenturou České republiky.

\section{Literatura}

Balvín, P., Vizina, A., Nesládková, M., and Kašpárek, L. (2015) Determinig Czech Republic's minimum residual discharges. The 14th International Symposium in the field of Water Management and Hydraulic Engineering.

Giorgi, F., Jones, C., and Asrar, G.R. (2006) Addressing climate information needs at the regional level: the CORDEX framework. Bulletin of the World Meteorologic Organization, 58, p. 175-183.

Beran, A. a Hanel, M. (2015) Definování zranitelných oblastí z hlediska nedostatku vody na území České republiky. VTEI, 57, Č. 4-5, ISSN 0322-8916.

Hanel, M., Kašpárek, L., Peláková, M., Beran, A., and Vizina, A. (2013) Evaluation of changes in deficit volumes: support for protection of localities suitable for construction of reservoirs. Considering Hydrological Change in Reservoir Planning and Management, IAHS-IAPSO-IASPEI Assembly. 
Hanel, M.. Kašpárek, L., Mrkvičková, M. aj. (2011) Odhad dopadů klimatické změny na hydrologickou bilanci v ČR a možná adaptační opatření. Praha: Výzkumný ústav vodohospodářský T. G. Masaryka v.v.i., $108 \mathrm{~s}$

Hanel, M. a Vizina, A. (2013) Hydrologické modelování dopadů změny klimatu. Praha: Česká zemědělská univerzita $v$ Praze, $102 \mathrm{~s}$.

Harris, I. and Jones, P.D. (2014) CRU TS3.22: Climatic Research Unit (CRU) Time-Series (TS) Version 3.22 of High Resolution Gridded Data of Month-by-month Variation in Climate (Jan. 1901- Dec. 2013). NCAS British Atmospheric Data Centre, 24th September 2014.

Horáček, S. aj. (2012) Možnosti zmírnění současných důsledků klimatické změny zlepšením akumulační schopnosti v povodí Rakovnického potoka (pilotní projekt). Praha: VúV TGM, 150 s.

Meinshausen, M., Smith, S.J., Calvin, K., Daniel, J.S., Kainuma, M.L.T., Lamarque, J.F., and Van Vuuren, D.P.P. (2011) The RCP greenhouse gas concentrations and their extensions from 1765 to 2300 . Climatic change, 109 (1-2), p. 213-241.

McMahon, T.A., Pegram, G.G.S., Vogel, R.M., and Peel, M.C. (2007) Revisiting storage-yield relationships using a global streamflow database. Advances in Water Resources, 30, p. 1858-1872.

MZe a MŽP. (2011) Generel území chráněných pro akumulaci povrchových vod a základní zásady využití těchto území. Praha: Ministerstvo zemědělství a Ministerstvo životního prostředí, 153 s.

Peláková, M. a Boersema, M. (2005) Odhad objemu nádrží potřebného pro kompenzaci poklesu odtoku vlivem klimatické změny. Praha: VúV TGM, 41 s.

Šěpánek, P., Zahradníček, P., and Huth, R. (2011) Interpolation techniques used for data quality control and calculation of technical series: an example of a Central European daily time series. IDÓJÁRÁS Quaterly Journal of the Hungarian Meteorological Service, 115 (1-2), p. 87-98.

Taylor, K.E., Stouffer, R.J., and Meehl, G.A. (2012) An Overview of CMIP5 and the experiment design Bull. Amer. Meteor. Soc., 93, p. 485-498.

Vizina, A., Horáček, S. a Hanel, M. (2015) Nové možnosti modelu BILAN. VTEI, 57, č. 4-5, ISSN 0322-8916.

Vogel, R.M. and Bolognese, R.A. (1995) Storage-reliability-resilience-yield relations for over-year wate supply systems. Water Resources Research, 31, p. 645-654.

\section{Autoři}

Ing. Roman Kožín ${ }^{1,2}$

凶roman_kozin@vuv.cz

doc. Ing. Martin Hanel, Ph.D.,2

凶martin_hanel@vuv.cz

Ing. Ladislav Kašpárek, CSc. ${ }^{1}$

凶ladislav_kasparek@vuv.cz

Ing. Martina Peláková1

凶martina_pelakova@vuv.cz

Ing. Adam Vizina, Ph.D.,

凶adam_vizina@vuv.cz

Mgr. Pavel Treml ${ }^{1}$

凶pavel_treml@vuv.cz

${ }^{1}$ Výzkumný ústav vodohospodářský T. G. Masaryka, v.v.i.

${ }^{2}$ Česká zemědělská univerzita v Praze

Příspěvek prošel lektorským řízením.
POSSIBLE COMPENSATION OF NEGATIVE CLIMATE CHANGE IMPACTS USING THE LOCALITIES FOR POTENTIAL ACCUMULATION OF SURFACE WATER

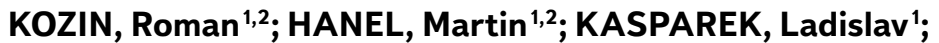 PELAKOVA, Martina ${ }^{1}$; VIZINA, Adam ${ }^{1,2}$; TREML, Pavel ${ }^{1}$}

${ }^{1}$ T. G. Masaryk Water Research Institute, p.r.i.

${ }^{2}$ Czech University of Life Sciences in Prague

Keywords: water reservoir - deficit - climate change - adaptation

The list of localities potentially suitable for accumulation of surface water (LASW) exists in the Czech Republic from the beginning of 20th century. It has been reduced several times from several hundreds to 65 localities which are now described in the Master Plan for LASW. The elementary information on the potential volume, conflicts with socio-industrial development, environmental protection etc. has been provided in the past. In the context of possible climate change in the future decades it is necessary to assess the extent to which the drought characteristics (severity, frequency) might change and whether the potential reservoirs at LASW might be able to compensate for such changes. The paper presents first results of a new research project, the aim of which is to provide information for the updates of the LASW Master Plan with respect to the suitability of each locality and the parameters of the reservoirs. 